\title{
Youths Participation in Maize Farming in Kaduna State
}

\author{
Abdulrahman Ali, I. Y. Ilu, T. Arokoyo, S. J. Auta and Y. M. Abdullahi \\ National Agricultural Extension and Research Liaison Services (NAERLS) \\ Ahmadu Bello University \\ Zaria, Nigeria
}

\begin{abstract}
The paper examines the level of youth's participation in maize farming in Lere and Fatika Agricultural Development Project (ADP) zones of Kaduna state. Results show that only $19.6 \%$ of the maize farmers falls within the age range of 25-35 years. Despite the involvement of ADPS, LGA and other non governmental organizations in extension activities in the area, the quantity of maize harvest was found to be below the recommended yield. This was found to be true for the younger age category of the farmers. The paper suggests the need for policy makers to improve on rural infrastructural development and extension activities in the area.
\end{abstract}

\section{INTRODUCTION}

Maize farming in Kaduna state has been given a lot of attention by extension organizations over the decades. Of recent, this includes the Agricultural Development Programmes (ADP's), Local Government Authorities (LGA's) and Non-Governmental Organizations like the SG 2000. This attention primarily was due to the need to improve maize cultivation given the ecological and comparative advantages of the area that favor maize cultivation.

However, given the low contribution of agriculture to the GDP and the increase in population, a lot more is expected from the youth in raising the yield levels of maize production, primarily as it serves as the main staple crop, hence advancing the growth of agriculture in the area. The youths constitute a moving force in the development of their communities. Auta et al. (2005) documented the limitations of youths in contributing to meaningful agricultural development as follows: greater majority of youths largely depend on their relations for subsistence, few youths engage in farming merely for subsistence and there is unavailability of credit facilities for farming purposes. Studies on the youth population levels and productivity are therefore considered important and relevant in addressing the increase in maize production in the state.

\section{Data and Model}

Farm level studies on youths involved in maize farming are not widely documented. This is probably because of paucity of relevant data. In response to the available data, this study examines one of the most important crops (maize) in Kaduna state. Two ADP zones (Lere and Maigana) were chosen for the study. Five villages were selected from Lere zone from which 30 farmers were randomly sampled namely: Danalhaji, Saminaka, Yarkasuwa, Lere and Raminkura and in Maigana zone, 30 farmers are randomly selected for the study. Structured questionnaires were administered by trained enumerators to the farmers during the 2004 
Journal of Agricultural Extension

Vol. 13 (2) December 2009

planting season. Data collected was mainly on the socioeconomic characteristics of the farmers, farming input sources and yield. Simple descriptive statistics was used to analyze the findings of the study.

\section{RESULTS AND DISCUSSION}

The figure below shows that out of the total sampled maize farmers in the study area, only 20 percent are of the younger age category. The figure shows that, few (20\%) farmers of the age range 25-35 were involved in maize farming in the maize producing area. Most $(80 \%)$ of the maize production was done by the older age category of farmers in the age rage of 36-76. The average yield of the farmers is also given in table 1 .

Figure 1: Age distribution of maize farmers in Lere and Fatika $(n=60)$

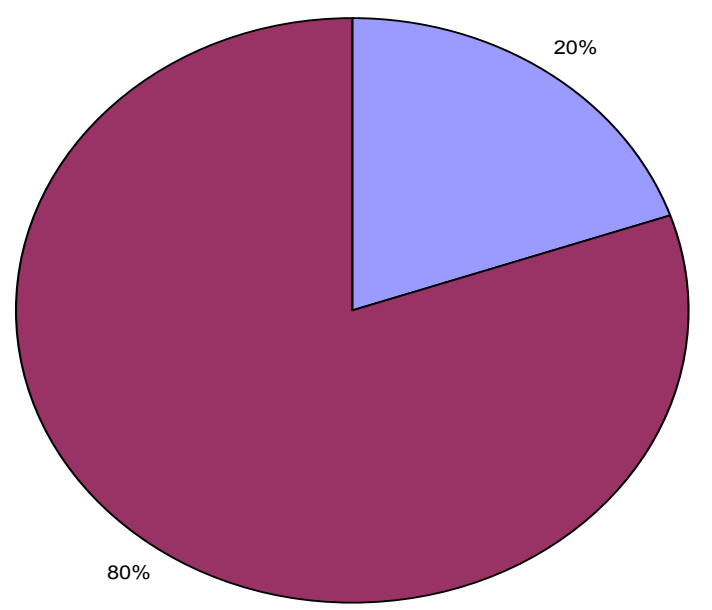

\section{Average farm size}

The table below shows that farmers in the age range of 36-76 realized a mean yield of 3.4 tons per hectare while farmers in the age range of 25-35 realized a mean yield of 2.4 tons per hectare. Yield realized from farmers in the age range of 25-35 however, falls below the recommended average yield of 3 tons per hectare for open pollinated seeds and 5tons per hectare using hybrid seeds (Iden and Showemimo, 2004).

TABLE: 1 Average Farm Size and yield

\begin{tabular}{ccc}
\hline Age range & Average farm size(ha) & Average yield(ha) \\
\hline $25-35$ & 0.7 & 2419 \\
$36-76$ & 2.0 & 3401 \\
\hline
\end{tabular}

Source Data survey 2004 
Note that farmers in the age range of 25-35 used improved (hybrid/open pollinated seeds) while almost all the farmers in the age range of 36-76 used improved seeds also. All the farmers used chemical fertilizers and pesticides sourced from the open market while improved seeds were sourced from seed companies. The results were further tested for relationships of variables using correlation analysis. This is given in table 2 above.

The Results show that farm size and yield are significant and highly correlated. However maize yield and age of farmers are weakly correlated but significant. Also type of seed is weakly correlated with maize yield and is not significant.

TABLE 2: Correlation Coefficients of Maize Yield, Type of Seed, Age of Farmers and Farm size

\begin{tabular}{|c|c|c|c|c|c|}
\hline & & $\begin{array}{c}\text { maize } \\
\text { yield(kg) }\end{array}$ & $\begin{array}{l}\text { type of } \\
\text { seed }\end{array}$ & $\begin{array}{l}\text { age of } \\
\text { farmer }\end{array}$ & $\begin{array}{c}\text { farm } \\
\text { size(ha) }\end{array}$ \\
\hline \multirow[t]{3}{*}{$\begin{array}{l}\text { Maize } \\
\text { yield(kg) }\end{array}$} & $\begin{array}{l}\text { Pearson } \\
\text { Correlation }\end{array}$ & 1 & .170 & $\left..352^{(* *}\right)$ & $.882\left({ }^{* *}\right)$ \\
\hline & Sig. (2-tailed) & & .195 & .006 & .000 \\
\hline & N & 60 & 60 & 60 & 60 \\
\hline \multirow[t]{3}{*}{ type of seed } & $\begin{array}{l}\text { Pearson } \\
\text { Correlation }\end{array}$ & .170 & 1 & $.323\left(^{*}\right)$ & $.312\left(^{*}\right)$ \\
\hline & Sig. (2-tailed) & .195 & & .012 & .015 \\
\hline & N & 60 & 60 & 60 & 60 \\
\hline \multirow[t]{3}{*}{$\begin{array}{l}\text { Age of } \\
\text { farmer }\end{array}$} & $\begin{array}{l}\text { Pearson } \\
\text { Correlation }\end{array}$ & $\left..3522^{(\star *}\right)$ & $.323\left(^{*}\right)$ & 1 & $.411\left(^{* *}\right)$ \\
\hline & Sig. (2-tailed) & .006 & .012 & & .001 \\
\hline & N & 60 & 60 & 60 & 60 \\
\hline \multirow[t]{5}{*}{$\begin{array}{l}\text { farm } \\
\text { size(ha) }\end{array}$} & $\begin{array}{l}\text { Pearson } \\
\text { Correlation }\end{array}$ & $.882\left({ }^{* *}\right)$ & $.312\left(^{*}\right)$ & $\left..411{ }^{(* *}\right)$ & 1 \\
\hline & Sig. (2-tailed) & .000 & .015 & .001 & \\
\hline & N & 60 & 60 & 60 & 60 \\
\hline & Sig. (2-tailed) & .518 & .257 & .289 & .742 \\
\hline & $\mathrm{N}$ & 60 & 60 & 60 & 60 \\
\hline
\end{tabular}

** Correlation is significant at the 0.01 level (2-tailed)

* Correlation is significant at the 0.05 level (2-tailed) 
Journal of Agricultural Extension

Vol. 13 (2) December 2009

\section{CONCLUSION AND POLICY OPTIONS}

Youth involvement in Maize farming is vital in addressing the food requirement in the country. Their involvement, besides addressing food security also addresses unemployment and poverty. However, many studies have documented that youths are more attracted to the cities and see farming as un-attractive. Perhaps this explains the low population of youths in maize farming in the study area. The danger here is that with the older farmers' final withdrawal from farming due to old age, the need for replacing them by young farmers will therefore arise. The youths do posses attributes critical to growth and development and constitute a major resource base (Arokoyo and Auta, 1992). The pertinent question then is, are the youth available and well educated to take over?

The study further revealed that although inputs for maize production; improved seeds and chemical were available from seed companies and open market, yield of the lower age category of the farmers was below the recommended level. This means their knowledge of maize production needs to be enhanced to enable them attain greater production. This can be done by organizing the youths into groups. The group can subsequently be trained by the various extension organizations. Group formation will guarantee them many benefits that among others include access to credit from credit institutions for those who may be interested in farming but have no cash backing, reduced cost of farming inputs and greater profit due to better price for their harvest. The need also arise for governmental intervention in further development activities in the study area. This may include infrastructural development in terms of roads, water and electricity. This will check the migration of youths from the villages to the urban areas and make farming attractive to the youths.

\section{REFERENCES}

Arokoyo, T and Auta, S.J. (1992) How to reach and work with rural youth. Proceedings of a national workshop on extension strategies for reaching rural youth.NAERLS/ABU Zaria.

Auta, S.J. Abdullahi, Y.M. Nasiru, M and Usman (2005) An asesment of rural youth involvement in Agriculture in Nigeria. A research report submitted to National Agricultural Extension and Research Liaision service.

Idem, N.U.A. and Showemimo F.A. (2004) Cereal crops of Nigeria: Principles of Production and Utilization. Ade Commercial Press. 